\title{
Conflicts Between Forestry and Wood-Processing Industry in Bosnia- Herzegovina: Reasons, Actors and Possible Solutions
}

\section{Bruno Marić}

University of Sarajevo,

Faculty of Forestry,

Zagrebačka 20

71000 Sarajevo

Bosnia-Herzegovina,

bruno.m.maric@gmail.com

Amila Brajić

University of Sarajevo,

Faculty of Forestry,

Zagrebačka 20,

71000 Sarajevo
Bosnia-Herzegovina

Mersudin Avdibegović

University of Sarajevo,

Faculty of Forestry,

Zagrebačka 20,

71000 Sarajevo

Bosnia-Herzegovina

Senka Mutabdžija
University of Sarajevo,
Faculty of Forestry,
Zagrebačka 20,
71000 Sarajevo
Bosnia-Herzegovina

\section{Abstract}

Background and purpose: Caused by appearance of new stakeholders and diversification of their interests towards forests, different forest-related conflicts emerged worldwide. As a country with economy in transition and relatively young democracy, Bosnia-Herzegovina might be suitable for understanding the roots, actors and varieties of these conflicts. This paper deals with the most frequent forest-related conflicts, main actors involved as well as undertaken actions in order to manage them in Bosnia-Herzegovina.

Materials and methods: The theoretical framework is based on the Conflict Management Progress Triangle consisting of three dimensions of conflict: substance, process and relations. As particular focus in this paper is given to conflicts between forestry and wood-processing industry, the primary parties in this study were public forestry companies and wood processing companies. For the purpose of this survey a special questionnaire has been designed. The survey population included the most important actors of forest and wood-processing industry as follows: ministries of forestry, nature protection and physical planning at all levels, managers/owners of wood-processing companies, managers of public forest

\section{Doni Blagojević}

European Forest Institute, Torikatu 34,

80100 Joensuu

Finland

\author{
Sabina Delić \\ University of Sarajevo, \\ Faculty of Forestry, \\ Zagrebačka 20, \\ 71000 Sarajevo \\ Bosnia-Herzegovina
}

\section{Dženan Bećirović \\ University of Sarajevo, Faculty of Forestry, Zagrebačka 20, 71000 Sarajevo Bosnia-Herzegovina \\ Špela Pezdevšek Malovrh}

Biotechnical Faculty, Department of Forestry Slovenia

companies and public forest administration, representatives of the most important environmental NGOs and professional associations, managers of protected areas and water management authorities, heads of forest research institutions, economy of chambers and international institutions. In total 136 questionnaires were collected, out of which 68 respondents identified conflicts between forestry and wood-processing industry as the most important ones.

Discussion and conclusions: The results show that the main causes of these conflicts are: differences in demand and supply of wood assortments, way of selling of wood assortments (including quantities and delivery dynamics) as well as wood assortments prices. As the most prominent action among the undertaken ones to manage the conflicts, the respondents underlined adoption of criteria for transparent selling of wood assortments. The results of this paper might be useful for both, public forest companies and wood-processing companies. Timely identification and implementation of possible solutions in order to overcome the most pronounced conflicts would increase competitive advantages for both sides.

Keywords: Forest-related conflicts, forestry, wood-processing industry, conflict management, Bosnia-Herzegovina 


\section{INTRODUCTION}

Forestry and wood-processing industry are traditionally the most important pillars of B-H economy. Besides, forestry together with agriculture has irreplaceable role for development of rural and remote areas in the country. Unlike other countries with economy in transition, B-H emerged from the war with almost totally destroyed infrastructure and ruined industry. In such circumstances, recovering of the national economy heavily depended on natural resources such as forests, water and minerals. In 1999, only three products (beech wood, aluminium and electrical energy) made $54 \%$ of the total export value of the Federation of $\mathrm{B}-\mathrm{H}$ [1]. On the other hand, some wider aspects such as globalisation and transition as well as new political framework in B-H (political pluralism, democracy, personal freedoms etc.), significantly influence the society demands towards natural resources. This caused appearance of new stakeholders with different and often confronted interests. In the context of joining to European integrations, prevailing global trends for nature protection, seem to be a binding framework for creating forest policy at the national level. Emerging of non-government sector leads to the new directions in forest policy through launching different actions intend to change day-to-day forest management practices. Possible forest resources shortage, induced by numerous initiatives to establish new protected areas, might seriously endanger economic viability of forest companies but also jeopardize employment of rural population. This leads to various cross-sectoral conflicts and disputes between national policies and local management practices. The variety and incompatibility of stakeholders' interests as well as power distribution among them creates the precondition for different types of forest-related conflicts.

Although B-H society unquestionably has many characteristics of post-conflict society, there are few literature sources that offer a systematic overview of conflicts by type, actors involved, conflict roots and intensity, resolving modalities and other important aspects of the issue. An interesting article about political conflicts in post-war B-H points that the intensity of conflicting quality in transitional societies mainly depends on readiness and competence of political actors in resolving or accommodating the conflict situations [2]. Basic social conflicts in B-H with the focus on national, religious, political and economic values are described in some textbooks [3]. Furthermore, a number of public debates and workshops were organized by different organizations in order to discuss different aspects of conflicts prevention [4] and solving [5].

At the regional level initial research about conflicts has been conducted and results presented through several papers [6-10]. The consistent overview of forest conflicts based on appropriate theoretical framework does not exist in B-H. This is not because of nonexistence of forest conflicts, on the contrary - conflicts are so diverse and serious to leave far behind the national research capacities. Due to political and historical circumstances, social and policy relevant forestry research was quite undeveloped, comparing to the traditional milieu of forestry research interests (e.g. forest ecology and silviculture, forest protection, utilization etc.). Still, some authors examined the phenomena of forest conflicts in a way or another, during few last years. Some potential conflicts in the context of different approaches in setting forest management goals were discussed in different papers [11, 12]. Another papers related to the national legislation collisions have identified some disputes between foresters and environmental authorities, mainly related to lack of cross-sectoral dialogue and responsibilities in protected areas management $[13,14]$. The way in which forest conflicts, particularly those regarding changing demands of the society towards forests might influence strategic and structural changes in forest enterprises is investigated in doctoral thesis defended at the Faculty of Forestry University of Sarajevo [15]. Although the Federal Strategy for Environment Protection [16] includes the chapters related to public participation and conflict management, all practical activities regarding establishing new protected areas are characterised by lack of theoretical framework to understand the nature of conflicts phenomena and thus cannot offer relevant policy recommendations or realistic conflict management solutions.

\section{MATHERIALS AND METHODS}

The objective of the study was to identify the most important conflicts between forestry and other sectors. According to De Vaus surveys are characterized by a structured or systematic set of data [17], in order to produce an overview of the conflicts at the country level, a structured questionnaire with few open questions and with cover letter explaining the background and purpose of the study, was designed and distributed to the top and middle level decision makers (survey population) within the all relevant institutions/organisations as follows: ministries of forestry, nature protection and physical planning at all levels, directors of public forest companies and public forest administration, directors of wood-processing enterprises, managers of protected areas and water management authorities, representatives of the most important environmental NGOs and professional association, heads of forest research institutions and representatives of private forest owners associations, representatives of economy of chambers and international institutions. 
Before the final sending to the representatives of the institutions, the questionnaire was pre-tested and improved based on the feedback results. The questionnaires were sent either by e-mail or fax, together with the initial information about the project as well as explanation of possible benefits the respondents might have from the results of the study. After the first round of received answers all the respondents who did not react were reminded with a phone call. In total two reminders were sent to all the respondents who did not response. The survey was conducted during the period October-December 2008 in both entities (the Federation of B-H and Republic of Srpska) and the response rate was calculated $64.7 \%$ which is appropriate for this kind of method. The data obtained were coded in the Excel sheet and transformed in the SPSS document for further statistical analysis. Statistical analysis was conducted in the SPSS version 15 , and included determination of frequencies for survey questions 1-6. Due to the structure of questionnaire survey analysis was compound from three parts. In the general part (which includes analysis of all 136 received questionnaires), the most important conflicts have been identified and basic data from the national survey research were presented. After the identification of the most expressed conflicts, the separate statistical analysis for the most specific type of conflicts has been done, forestry versus wood processing industry and forestry versus nature protection. Out of 136 questionnaires, 68 identified forestry vs. wood processing industry while 30 identified forestry vs. nature protection as the most important conflict.

Each conflict consists of main cause of disagreement, involved stakeholders, time and spatial frame, methods for conflict management, results and consequences of conflicts. According to Walker and Daniels all definitions of conflicts involve central elements of conflict: perceived incompatibility, interests, goals, aspirations, two or more interdependent parties, incentives to cooperate and compete, interaction, communication, bargaining/negotiation and strategy [18]. Conflict becomes more complex when more than two stakeholders are involved. Each stakeholder has specific role in conflict, conflict management and final outcome of conflict. Positive role can be: readiness for cooperation, tolerance, maximal engagement, good communication skills, readiness for negotiation and compromise while from the other side negative role can be expressed in the predisposition for the conflict, unwillingness for cooperation, latency, destructive actions and lack of communication with other stakeholders. By definition from Walker and Daniels three kinds of parties may appear in any conflict situation. Primary parties perceive that their goals are incompatible with another and interact di- rectly with each other in pursuit of their objectives. Secondary parties have a vested interest in or may be affected directly by the conflict and its outcome, but for some reasons (such as inadequate resources, lack of access, perception of inappropriateness) are not directly involved. Secondary parties are potential coalition members, and may become primary parties at some point. Peripheral parties have an interest in the conflict and outcome but are not affected directly.

The process of conflict management starts by identification of conflict, involved stakeholders and doing first steps in the establishing the communication between confronted stakeholders. The Conflict Management Progress Triangle [18] was adopted as conceptual theoretical framework of this research (Figure 1).

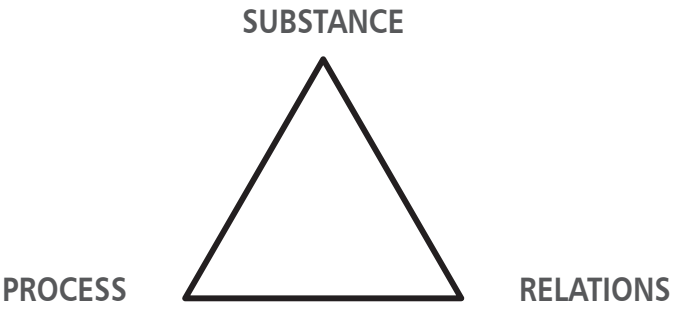

\section{FIGURE 1}

Conflict Management Progress Triangle

The conflict management progress triangle can serve as a basic model for understanding the nature of a conflict situation. Its design suggests the importance of determining the substantive, procedural and relationship factors in any conflict. Within these dimensions, other conflict elements such as interdependence, parties, roles, goals, issues and sources of incompatibility can be reviewed. As an assessment is a first step in a process of constructive conflict management, this triangle may be useful as an assessment tool. Under the substance dimension of conflict, one can assume sources of conflicts and what conflicts are about (money, power, emotions, ideologies, values, information etc.). The process dimension is about the way, in which conflict was occurred, aspect of space and time, how it develops (institutionally or personally, democratically or autocratically) and what might be the consequences for policy development. The relations dimension includes actors and relations between them, power distribution, level of trusts, knowledge and skills they possess as well as creating alliances and lobbies. Cultural and policy development perspectives of the conflicts and conflict management are also important [19].

Conflict management approaches also have the same three main attributes. In successful conflict management, the type of management approach 
corresponds to the main attributes of conflicts. Substantive conflict (e.g. harvesting versus conservation of rare species) might be solved by substance-oriented approach (e.g. creating multipurpose management plan or by excluding one of these two activities in the area of concern). Procedural-oriented approach can be used to manage procedural conflict (e.g. conflict about non-transparent proclaiming of the Law on protected area can be managed by organizing the public debates in local communities). Following the same logic, relations-oriented approach (e.g. fair compensation policy) can be used to manage stakeholders' relations (e.g. conflict between different stakeholders regarding ownership/using rights.).

\section{RESULTS AND DISCUSSION}

In order to find out which are the most important conflicts in Bosnia and Herzegovina respondents were asked in the questionnaire to select the most important conflict among 12 offered conflicts. Conflict between forestry and wood processing industry is identified in the $\mathrm{B}-\mathrm{H}$ as the most important conflict ( $50 \%$ of respondents) (Figure 2). As the second most important conflict is identified conflict between forestry and nature protection ( $21 \%$ of respondents). On the third place is conflict between forestry and construction sector. There are other conflicts identified such as: forestry and inefficient courts, forestry and grazing, forestry and collection of NWFPs and forestry and mining ( $0.7 \%)$ but not in the significant percentage as previous mentioned.

For the purpose of this paper from now on we will focus on the conflict between forestry and wood processing industry, identified as the most important one.

Main causes of conflict (Figure 3) are as follows: for the conflict between forestry and wood processing industry respondents identified differences in demand and supply of wood assortments (36.7\%), quantities,

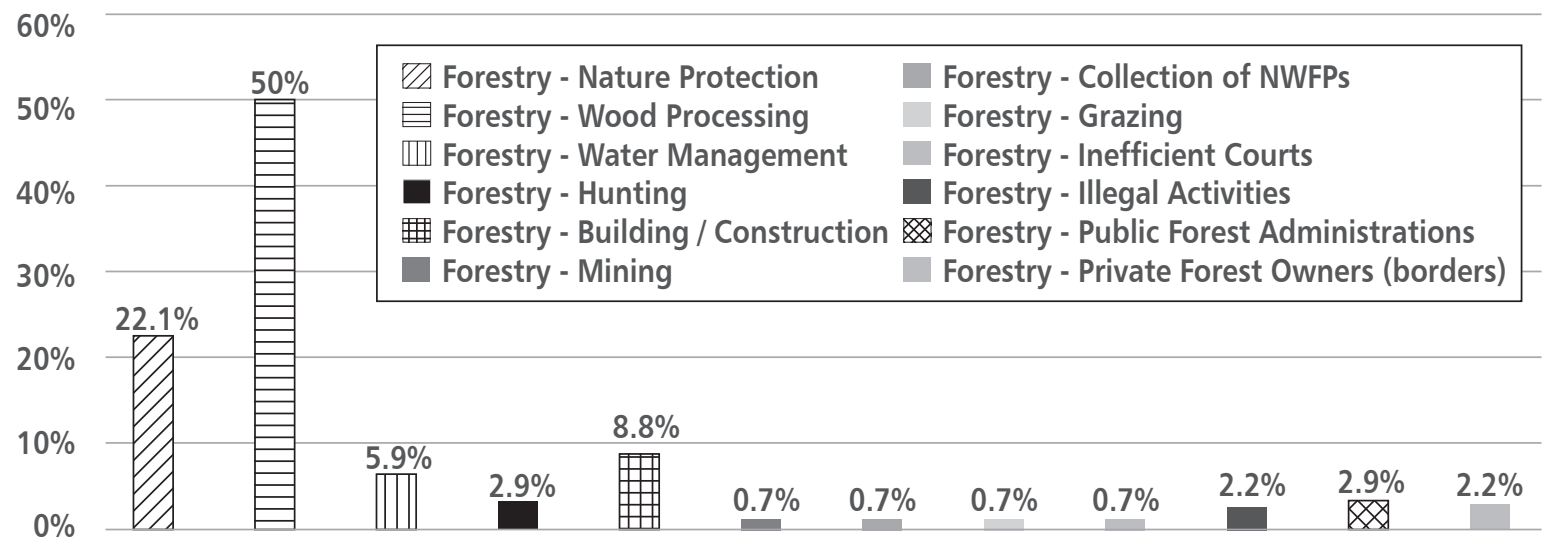

FIGURE 2

The most important forest related conflicts

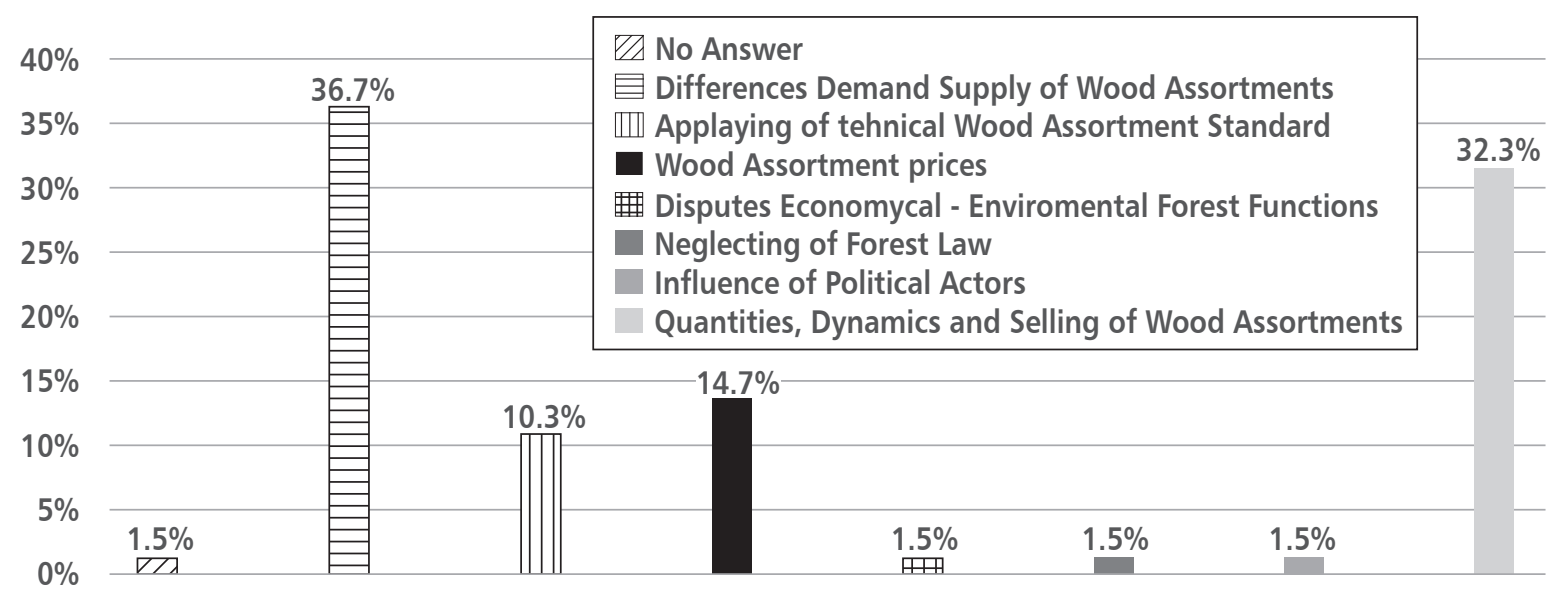

FIGURE 3

Main cause of the conflict between forestry and wood processing industry 
dynamics and selling of wood assortments (32.3\%) and wood assortments prices (14.7\%).

Conflict between forestry and wood processing industry occurs because processing capacities are bigger that production capacities. Each year forest companies can offer amount of wood assortments determined by their management plans. Since demand is bigger than offer there is always price of wood assortments as a limitation factor, followed by different quantities distributed to different wood processing companies.

One can conclude that conflict between forestry and wood processing industry is quite frequent (Figure 4). Majority of the respondent recognized conflict as a frequent and very frequent more than (67\%). Wood processing capacities are far bigger than annual cut timber volume, since there are a huge number of wood processing companies which are competing for the raw material conflicts are unavoidable. In fair conditions on market each wood processing company should get quantity of raw material proportional to its size, but very often that is not the case. Larger wood companies occupy larger quantities of raw materials which directly influence on the smaller companies. Although the quantity is very often mentioned as a main cause there is also a problem with quality of wood assortments. Wood processing companies are accusing forest companies for low quality of wood assortments in a way that the raw material second class is sold as a first class material. From the other side forest companies are not satisfied with obtained prices of wood assortments.

Man organizations involved in the conflicts are forest companies (33.3\%) and wood processing companies (33.3\%) since we are speaking about conflict between forestry and wood processing industry (Figure 5). Beside the primary parties in the conflict it is important to mentioned secondary party which is identified as local politicians/government with (7.8\%). Secondary party in this case local politicians have very important role in the conflict in a way that they are lobbying and influencing on the decisions of the management of the forest companies, which are in the most of the cases members of the political parties. Their influence is affecting

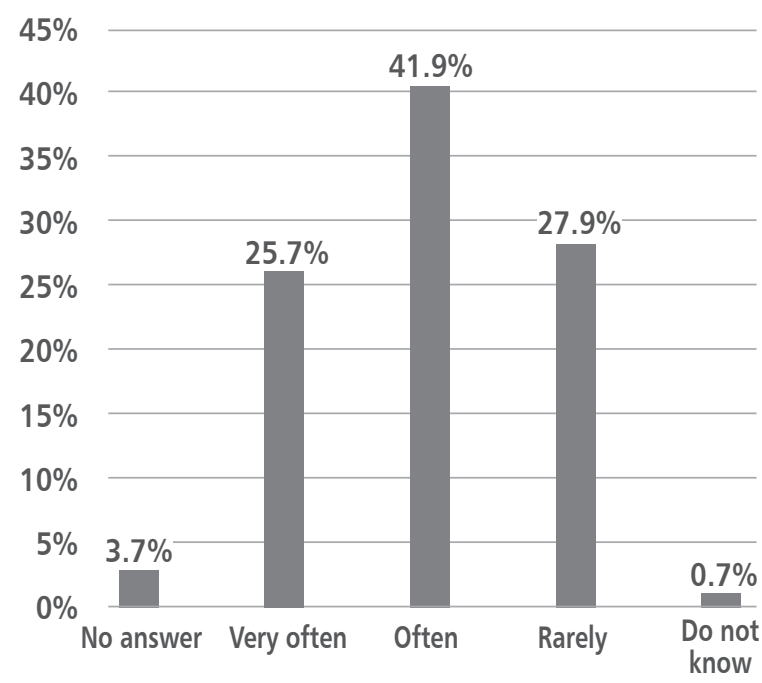

\section{FIGURE 4}

Frequency of the conflict

decisions regarding the distribution of the raw material to the wood processing companies. Sometimes the same politicians are owners of the wood processing companies or have other interest to lobby for certain company. Sometimes lobbying activities which are influencing dynamics of delivery, quantity and quality of raw material are done for preserving social peace, in order to provide raw material to the companies which are employing big number of employees.

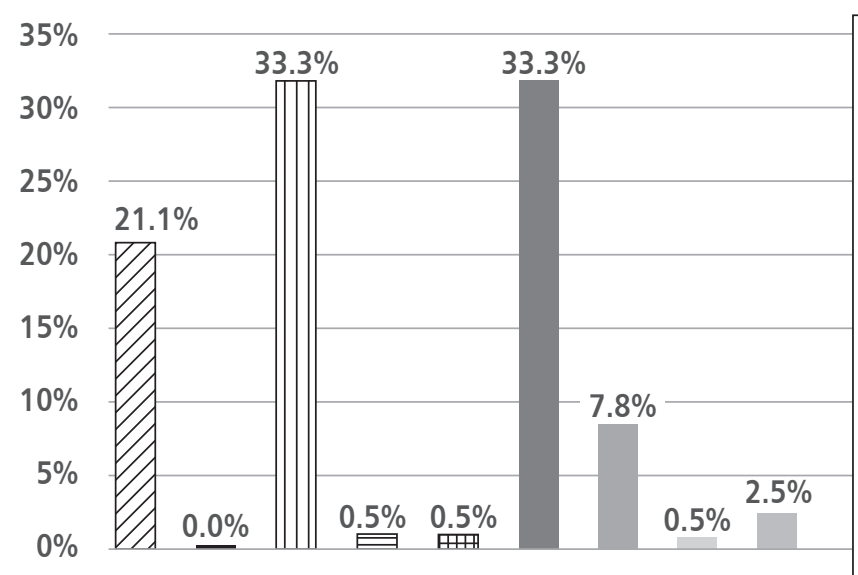

$\llbracket$ No answer

- Public Forest Administration Cantonal Level

미 Public forest Enterprices

目 Local Communities / Population

NGO-s

Wood Prcessing Companies

Local Politicans / Goverment

Ministry of Agriculture Water

Management and Forestry Cantonal Level

Ministry of Agriculture Water

Management and Forestry Entity Level

Organizations involved in the conflict 


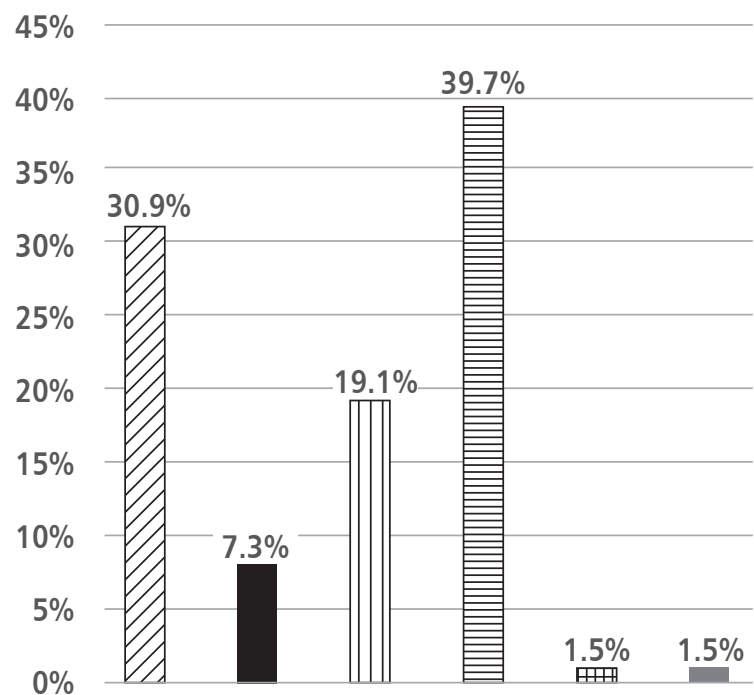

$\square$ Latent Conflict $\quad$ 目 Conflict is Now Benig Settled

Emerging Conflict Conflict is Settled

미 Escalating Conflict Do Not Know

\section{FIGURE 6}

Stage of the conflict

Conflict between forestry and wood processing industry is in a stage that conflict is settled (39.7\%). Vice versa (30.9\%) of respondents thinks that conflict is latent, while $(19.3 \%)$ of respondents has opinion that conflict is in escalating stage (Figure 6). These different opinions are present because there are different dynamics of selling of raw material. The dy- namics of selling raw material depends mostly from the demand and from the season. One can conclude that conflict is always present, in some periods is more emphasised while in some periods is not visible

On the question which actions were done from policy makers in order to manage conflict majority of respondents did not answer (36.7\%). Possible reason for that might be that respondents were not able to recognize any of the actions or these actions were not implemented at all. (16.2\%) of respondents identified adoption of criteria for transparent selling of wood assortments as the most important one (Figure 7). By the criteria for transparent selling of wood assortments is meant that all wood processing companies are included in the process of distribution of raw material by fulfilling very often criteria such as: decision on registered services, registration on the court, evidence on paid tax, number of employees, processing coefficient and other criteria. Respondents mentioned other actions which were undertaken in the specific cases in their companies $(13.2 \%)$. By the declarative contribution to the solving the conflict $(10.3 \%)$ respondents consider that no concrete actions except talk were done. Conflict was managed through the conversation and communication between affected parties.

\section{DISCUSSION AND CONCLUSIONS}

This paper identified the most important conflicts in Bosnia-Herzegovina and focus on the conflict between forestry and wood processing industry. Results indicated types of conflicts, primary and secondary par-

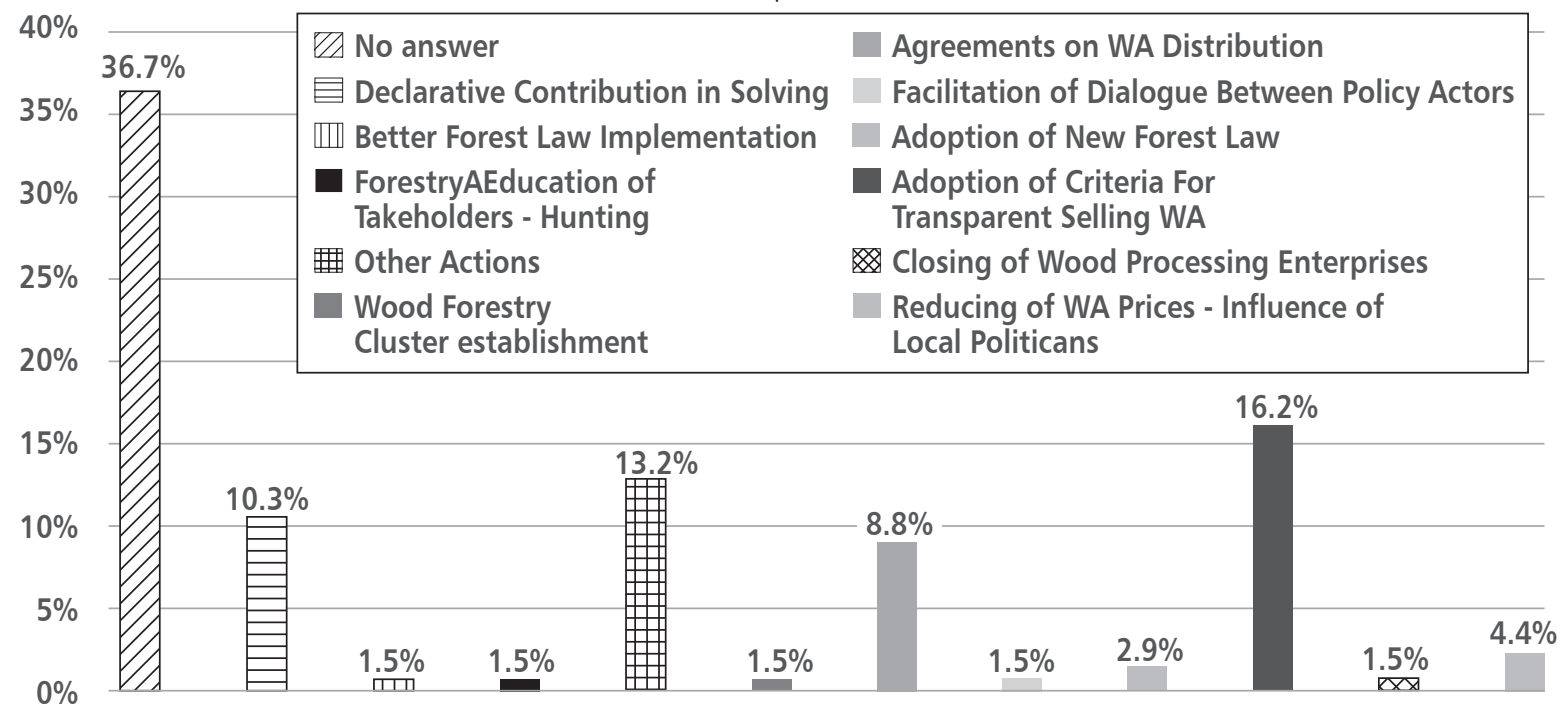


ties/actors involved in the conflict, causes of conflicts and what were the actions done from policy makers in order to manage conflict. Primary parties in this conflict were forestry and wood processing companies. Main causes of the conflict were: differences in demand and supply of wood assortments, quantities, dynamics and selling of wood assortments and wood assortments prices. Among the undertaken actions to manage the conflict respondents identified adoption of criteria for transparent selling of wood assortments and declarative contribution through the communication of conflicted parties. This overview of types of conflicts, actors and possible solutions can contribute to the understanding and accepting the existence of the conflicts which were neglected in the period of socialism and contribute to the forest policy development in countries in transition such as B-H. Results in the paper demonstrate that conflicts are present in the forest sector of $\mathrm{B}-\mathrm{H}$ and as such request more attention and efforts in order to be better managed.

As concerns the conflict as a social phenomenon conflicts are drivers of change, sometimes conflicts are necessary to provoke progress. Conflicts can impact policy development in both, positive and negative way, depending on how they are managed. This impact depends also on conflict intensity and its relevance in given political environment. Sometimes very intensive conflicts (e.g. devastation of huge forest areas) have limited political relevance due to many reasons (forestry is not high ranked in the political agenda, the politicians are involved in conflicts, there is lack of information about the conflicts etc.). As it is already stated, readiness of political actors to change the situation is the essential preconditions for any conflict impact on policy development.

Based on the results of the paper it can be concluded that there are certain changes in policy making attitudes towards the role and significance of the conflict and need for conflict management. It was mentioned that policy makers have significant role in the conflict management. If there is no political will to manage the conflict the process of conflict management will be much slower and will not generate satisfaction of conflicted parties. The interest is the main engine in managing conflict, if political actors estimate that there is no interest in managing conflict, conflicted parties will experience more difficulties in the process of mutual agreement which will be more time consuming.

In the future more attention to this phenomenon should be dedicated, meaning that more deep and detailed research should be done in order to understand the core of the problems and to establish procedures for management of conflicts if possible. More open decision making process including more participants could cause constructive conflict management which will make natural social changes as a main component of democratic societies. The main goal of this paper is to give an overview of existing conflicts in the forest sector and to initiate more intensive research on this issue in the future.

\section{REFERENCES}

1. ĐULAN M, BEŠLIĆ E 1999 Izvoz po svaku cijenu, Oslobođenje, 30.09.1999. Sarajevo

2. ŠAČIĆ N 2007 Political Conflicts in Post-War Bosnia and Herzegovina, Odjek, No. 1/2007, Sarajevo: 13-16

3. VIDAKOVIĆ J 2003 Društveni konflikti Bosna i Hercegovina, Zavod za udžbenike i nastavna sredstva Sarajevo

4. Research and Documentation Center Sarajevo, Conflict Prevention Public Debates. Available at: www.idc.org. ba/project/public_debates.htm (Accessed: 13 September 2010)

5. Women's Association Medica Zenica, Workshop for Nonviolent Conflict Resolving. Available at: http://www.medicazenica.org/index.php?option=com_content\&view $=$ art icle\&id=57\&Itemid = 18 (Accessed: 05 September 2011)

6. VULETIĆ D, KRAJTER S, KIŠ K, POSAVEC S, AVDIBEGOVIĆ M, BLAGOJEVIĆ D, MARIĆ B, PALADINIĆ E 2009 Conflicts between forestry and nature protection - case studies of two nature parks in Croatia. Period biol 111 (4): 467-478
7. VULETIĆ D, STOJANOVSKA M, AVDIBEGOVIĆ M, NEVENIĆ R, PETROVIĆ N, POSAVEC S, HASKA H, PERI L, BLAGOJEVIĆ D 2010 Forest-related Conflicts in the South-east European Region: Regional aspects and case studies in Albania, Bosnia-Herzegovina, Croatia, Macedonia and Serbia. In: Tuomasjukka T (ed) Forest Policy and Economics in Support of Good Governance, EFI Proceedings No 58: 117129

8. NEVENIĆ R, RAKONJAC L, PODUŠKA Z, GAGIĆ R 2011 Collisions and linkages between forestry and environmental policies in South East Europe (SEE) region. Scientific research and essay 6: 5492-5500

9. KIŠ K, AVDIBEGOVIĆ M 2009 Legal and Practical aspects of Cross-sectoral Conflicts on the example of the $\mathrm{Na}$ tional Park "Sjeverni Velebit", Naše šume, UŠIT, 14/15, Sarajevo, B-H: 19-24

10. KIŠ K 2010 Understanding social conflicts between forestry and nature protection sectors: case study Velebit Mountain. SEEFOR 1 (2): 81-90 
11. AVDIBEGOVIĆ M 2004 Recent Forest Policy Developments in Bosnia and Herzegovina. In: Jansky L, Nevenić R, Tikkanen I, Pajari B (eds) Forests in transition II: Challenges in Strengthening of Capacities for Forest Policy Developments in Countries with Economies in Transition, UNU, Tokyo: 223-244

12. AVDIBEGOVIĆ M, ŠAKOVIĆ Š, MEKIĆ F, DELIĆ S 2005 Forest Management in B-H: Multiple Use Forestry versus Primary Function Forest Management. Proceedings of the Third Symposium of veterinary, agriculture, forestry and biotechnology in B-H, Sanski Most

13. AVDIBEGOVIĆ M, KRILAŠEVIĆ E, SELMANAGIĆ A 2006 Collision between Regulations in Forest Law and Environment Related Legislation in the Federation of $\mathrm{B}-\mathrm{H}$. IUFRO Division 6, RG 6.13.00 - Social, Economic, Information and Policy Sciences, Proceedings of the 8th International Symposium on Legal Aspects of European Forest Sustainable Development, Department of Forest L, Law, Faculty of Forestry, Istanbul

14. AVDIBEGOVIĆ M, SRNDOVIĆ R 2006 Legislation on Protected Areas in Bosnia-Herzegovina. Proceedings of the International Scientific Conference: Forest Ecosystem
Management of National Parks and other Protected Areas, Jahorina

15. AVDIBEGOVIĆ M 2006 Reengineering of Forestry Business Systems towards Satisfying Social Aspects of Forest Management in B-H. Dissertation, University of Sarajevo, Faculty of Forestry, Sarajevo, p 167

16. Federal Ministry of Environment and Tourism, Federal Strategy for Environment Protection. Available at: www. okolis.ba (Accessed: 05 December 2011)

17. DE VAUS D 2002 Surveys in social research. In: Bulmer M (ed) Routledge Taylor and Francis Group London, pp 3

18. WALKER G B, DANIELS S E 1997 Foundations of Natural Resource Conflict: Conflict Theory and Public Policy. In: Solberg B, Miina S (eds) Conflict Management and Public Participation in Land Management, EFI proceedings 14, Joensuu: 13-33

19. HELLSTROM E 2001 Conflict Cultures - Qualitative Comparative Analysis of Environmental Conflicts in Forestry. Silva Fennica, Monographs, 2, Helsinki, p 109 

